\title{
PHENOMENON OF A TRANSACTIONAL RENT IN AGRARIAN BUSINESS Viktor Barkhatov $^{1}$, Daria Bents ${ }^{2}$, Elena Silova $^{3}$, Elena Kozlova $^{4}$
}

\begin{abstract}
The phenomenon of a transactional rent in agrarian business in Russian regions is studied in the presented paperwork. The authors have found such phenomenon while they were analyzing contractual relations in regional agrarian branches. The research was supported by the state grant for young scientists in 2015-2016. The authors gathered a set of qualitative and quantitative results exploring the problem of agrarian contractual relations.

The article's purpose is to research the nature and forms of transactional rent, to develop a technique of the quantitative assessment of contractual relations' efficiency, and to evaluate that level.

Transactional rent is understood as the income gained by one subject (contractor) while there are reasons to suppose that this income shall belong to the other subject of a transaction (if the market is perfect). Transactional rent is a result of imperfection in the market mechanism. The authors consider inefficiency of the contractual relations as the main problem of agrarian market functioning. That is shown by the presence of high market barriers, discriminating conditions, multiplicity of subjects of a contractual chain, and lack of regulation of contractual relations in business practice. The high prices of food for customers, monopolization of markets at the level of retail trade, high level of shadow operations in this market and, respectively, imperfection of monitoring over food quality are the consequences of similar inefficiencies of contractual relations. Threat of food security and regional economic stability in general can arise as the result of a high level of transactional rent. The research is based on neoinstitutional methodology. Key methods of research are statistical and econometric as a method of economic modeling. For carrying out empirical research, authors have access to the paid database (FIRA PRO) where a huge number of statistical information on the agrarian market is available. For the analysis of the level of transactional rent in agrarian business, the authors use a technique with such indicators as effectiveness ratio of the contract relations and coefficient of opportunism. In the conducted statistical research, it is established that the greatest transactional rent is formed at the third element of an agrarian contract chain (wholesale trade).
\end{abstract}

JEL Classification Numbers: D01, D02, D23; DOI: http://dx.doi.org/10.12955/cbup.v6.1128

Keywords: rent, transaction, contract, opportunism, market, institute

\section{Introduction}

The development of the agrarian industry of Russia is one of its priorities for regional economic policy. Agrarian business is mainly connected with a problem of national and regional food security. It plays huge role considering the fact that Russia was an agrarian country for the most part of its history. Therefore, the agrarian business plays an important role in the economies of many Russian regions of agrarian significance. The investigation of institutional regulation of agrarian markets by the authors established a number of serious problems such as poor quality of the institutional environment, lack of cooperation mechanisms, and low contractual relations' efficiency. In particular, examination of a problem of transactional rent nature in the sector has revealed that there are rather long contractual chains which cause forming of transactional rent. These chains often include those subjects (intermediaries) whose activity seriously complicates a situation in industry. These intermediaries set the discriminating prices for producers, monopolize the market, obtain market power, and establish inflated prices on food production for ultimate consumers. Their actions lead to the strengthening of imperfection in agrarian markets and generate high transactional costs of other economic subjects. The authors suggest that there is such phenomenon as a transactional rent, which arises in the contractual relations in agrarian business. Transactional rent is understood as the income gained as a result of market mechanism imperfection and redistributed in favor of one subject of the transaction while there is basis to believe that this income has to belong to the other subject if the market is perfect and behavioral opportunism is fully absent. The goal of this paper is to study the mechanism of formation and features of a transactional rent as economic phenomenon in more detail.

\section{Transactional rent: features}

The category of a rent arose initially in classical political economy as the basis for regulating relations between the land owner and the tenant. The land rent's entity was explained by classics differently. Ricardo (1817) considered it as a way of receiving income on property and payments for the natural resource owned by the land owner. Petty (1662) emphasized that rent is not connected to

\footnotetext{
${ }^{1}$ Chelyabinsk State University, ieo-science@csu.ru

${ }^{2}$ Chelyabinsk State University, benz@csu.ru

${ }^{3}$ Chelyabinsk State University, metod@csu.ru

${ }^{4}$ Chelyabinsk State University, kozlova@csu.ru
} 
implementation of business activity. He revealed a monetary and land types of a rent, having carried to rent income gained by owners from land, machines, buildings lease and banking percent. In this concept, the rent is the excess product which the land owner keeps after compensation of the spent production elements. Also, Petty revealed a rent on location. Smith (1776) considered the rent as a part of the product price as well as proving that rent depended on demand. This author showed that the rent could arise also in the case of possession of mines, forested areas and other natural resources. This idea was developed afterwards by Ricardo (1817), who was analyzing a problem regarding the determination of a mine's rent. Ricardo introduced for scientific use a concept of a first type differential rent. He showed that mines gave a rent depending on quality of the product received from them. James Anderson (1777) marked out the reasons of this particular rent's formation: soil quality (fertility) and activities' extension at the land area.

Marx (1894) was an economist philosopher who deeply researched the problems of rent. This author pointed out that rent was arisen only if the land had been processed by a worker. Hence, labour is a key foundation for rent. Marx selects a differential rent of the first type; it is created on the best - most fertile and with best location - lands, and the second type; it is created as a result of an increase in labor productivity and an absolute rent - the income from land ownership that does not depend on its quality and the technologies of processing used.

The neoclassical school expanded the idea of the economic nature of a rent, considering it as income from any production factor. The modern researchers of a rent, as a rule, share the following belief: the rent brings an excess profit to the owners who possessed the rare resources.

The most important reason of the formation of absolute rent, according to Meshcherov (2012), is the monopoly for the earth as a property object. This author provides such conditions of rent's formation: a demand - for absolute rent, and a supply - for differential rent. Meshcherov also emphasizes a difference in concepts of rent resources and production factors. Although these individuals shared the dominated idea that rent represents a form of owners' income for extended periods of time in the economic theory, Meshcherov claims that the property on rent resources is a "set of the rights system which provides assignment of a rent" and connects rent's formation with monopolization in production and in the market. He emphasizes appearance of a large number of various rent resources in the modern economy and marked out different rent forms such as agricultural, oil, transport, townplanning, technological, financial, information, status, etc.

In current research devoted to a rent, we meet natural and not natural types of the rent. Tomilov (2010) studies a social phenomenon of a rent regarding abilities, which appear as a result of the possession of professional abilities and skills. Sirotkin (2014) explores the nature of academic rent, which is being formed at universities.

Alexandrova (2011) studies the nature of a status rent, defining it "as a part of income gained by the subject of the economic relations as a result of monopolization and privatization of official functions and from use of the status". This author selects the following status rent's features: specific form of ownership, inseparability from the official status, illegitimacy of functions' assignment process, functioning in the specific market, an ability to generate rent (combination of circumstances, generating a status rent), evolutionary character, etc. Alexandrova studies the institutional basis of status rent's formation and considers economic interests - lobbyist activity and isolation of bureaucrats interests - as the important reason of the status rent origin.

Now it is necessary to explore the transactional rent's specifics.

The first feature of a transactional rent is that it arises not in the production sphere, but in the exchange sphere (the contractual relations). This sphere became an object of analysis by neoinstitutional theory, and first of all by R. Coase (1937). Thus, there is an important question to find out a source of this rent. Transactional rent arises at monopolized markets, which are shown in the following: cartel conspiracies between oligopolies controlling one of levels of a contractual chain (for example, processing enterprises or retail chain stores), the discriminating pricing, high barriers, informational asymmetry between the subjects of contracts, etc. Hence, the transactional rent arises in the imperfect markets and is closely connected with the market power at one of the partners. Other conditions of transactional rent's formation are informational asymmetry and opportunism of economic subjects in contractual relations. The third feature is connected with the influence of a transactional rent on the 
contract relations. Consequences of a transactional rent are negative for the market in general and they are expressed in its further market monopolization, in increasing final market prices, and in decreasing of return rates of producers and farmers (first subject in the contractual rent).

\section{Concept headings}

The purpose of this research is to reveal the elements of contract agrarian chains where the biggest transactional rent is being formed. That will help in creating an effective regional agrarian policy.

Excess growth of the price of ultimate products becomes the result of opportunism of contract chain agents. To develop an evaluation technique of behavioral opportunism level, it is necessary to determine the level of excess growth of the price.

The standard agrarian chain includes such elements as farmer, manufacturer, wholesale merchandiser, retailer and ultimate consumer. The suggested technique was evaluated by Bents and Silova (2016).

We can see that the realization price of $i$-agent becomes, some kind of, prime cost for the $i+1-$ agent:

$$
C_{i+1}=C_{i}+X_{i}
$$

where $C_{i}$-prime cost for $i$-agent,

$X_{i}$ - trade profit for $i$-agent,

$C_{i+1}$ - prime cost for $i+1$-agent.

As a result, the ultimate consumer buys production at the price of $P_{4}$ :

$$
P_{4}=C_{4}+X_{4}
$$

where $P_{4}$-the ultimate price,

$C_{4}$ - prime cost for retailer,

$X_{4}$ - trade profit for retailer.

As the studied chain consists of five subjects, the number of price growth stages is at least four. Let us consider that the trade profit at each stage includes both a normal level, and an extra level:

$$
X_{i}=X_{i}^{\text {norm }}+X_{i}^{\text {extra }}
$$

where $X_{i}$ - trade profit for $i$-agent,

$X_{i}{ }^{n o r m}$ - normal trade profit for $i$-agent,

$X_{i}{ }^{\text {extra }}$ - extra trade profit for $i$-agent.

Let us consider that the behavioral opportunism of each of four contractual relations' subjects (apart from the consumer) is evident in a possibility of realization the product at the price containing an extra trade profit.

Let us enter the coefficient of behavioral opportunism $k_{o p}$ and coordinate it to the level of an extra trade profit $X_{i}{ }^{\text {extra }}$.

Besides, we consider that the extra trade profit includes extra transaction costs. In turn, they are also a source of opportunism of mentioned subjects.

Therefore, with growth of opportunism level the contractual relations efficiency will be reduce. That is why this efficiency of the contractual relations will be inversely proportional to opportunism level:

$$
k_{E C R}=\frac{1}{k_{o p}},
$$

where $k_{o p}$ - the level of behavioral opportunism,

$k_{E C R}$ - the level of the contractual relations efficiency.

We present the table of an assessment of the extra profit level, using the coefficient of behavioral opportunism and the coefficient of contractual relations efficiency (Table 1). 


\begin{tabular}{|c|c|c|c|}
\hline № & $\begin{array}{c}\text { Extra trade profit to the } \\
\text { Price, } \% \\
\left(X_{i}^{\text {extra }} / P_{i}\right) \\
\end{array}$ & $\begin{array}{c}\text { The level of behavioral } \\
\text { opportunism }\left(k_{o p}\right)\end{array}$ & $\begin{array}{l}\text { The level of the contractual } \\
\text { relations efficiency } \\
\left(k_{E C R}\right)\end{array}$ \\
\hline 1 & 0 & 0 & $\max$ \\
\hline 2 & $1-5$ & 1 & 1 \\
\hline 3 & $6-10$ & 2 & 0,5 \\
\hline 4 & $11-15$ & 3 & 0,33 \\
\hline \multirow[t]{2}{*}{5} & $16-20$ & 4 & 0,25 \\
\hline & $\ldots$ & $\ldots$ & $\ldots$ \\
\hline
\end{tabular}

Source: evaluated by authors according to financial statements of the enterprises

In practice to determine the level of an extra trade profit, as well as the level of all trade profit in general, is rather difficult. Therefore, we offer to determine the mentioned rates through calculation of ratio on sales $(R O S)$. The simplified formula of its calculation is as follows:

$$
R O S=\frac{P F_{\text {gross }}}{T R}=\frac{Q \cdot(P-C)}{Q \cdot P}=\frac{P-C}{P}=\frac{C+X-C}{P}=\frac{X}{P}=\frac{X^{\text {norm }}+X^{\text {extra }}}{P},
$$

(5)

$$
\begin{aligned}
& \text { where } R O S-\text { ratio on sales, } \\
& P F_{\text {gross }}-\text { gross profit, } \\
& T R \text { - total rent, } \\
& Q-\text { quantity of product, } \\
& P-\text { price, } \\
& \text { C - prime costs, } \\
& X-\text { total trade profit, } \\
& X^{\text {norm }} \text { - normal trade profit, } \\
& X^{\text {extra }} \text { - extra trade profit. }
\end{aligned}
$$

Thus, through excess ratio on sales over normal level we can find the level of behavioral opportunism and the level of contractual relations efficiency using the data in Table 1.

\section{Results}

The research of a transactional rent is based on the statistical information about the enterprises of the Chelyabinsk and Kurgan regions occupied in the agrarian industry (Table 2).

The enterprises of the first element of contract chain (farmers, producers) have the smallest profitability of sales. In 2014, profitability was extremely effective for the Russian agrarians due to the growth in grain exports, which in turn led to the growth of indicators in 2015. However, reduction of grain prices and oversaturation of the domestic market continues to have a negative influence on the market overall. Profitability of sales in vegetable growing did not exceed values of an indicator of other elements of contractual chain until 2014. However, the import ban of agricultural production for certain foreign producers in 2014 in an effort to protect domestic producers became an essential driver of this business growth.

The enterprises of the second element of an agrarian chain, due to the lack of entry into large markets and the high competition in industry, continue to depend on the purchase prices established by the enterprises of wholesale trade.

The carried-out analysis showed that the highest level of opportunism is observed at the third element of an agrarian contractual chain. The purchase of production at producers for the purpose of the subsequent resale caused the highest profitability indicators at the enterprises of wholesale trade. On the one hand, existence of the third element of an agrarian chain leads to decrease in the expenses connected with storage and product sales for producers, on the other hand it is a source of discriminating pricing.

Sales profitability of retail chain stores throughout the analyzed period showed steady growth in comparison with the enterprises of other agrarian chain subjects. It allows to draw a conclusion that consumers make essential profit not for producers, but for retail chain stores. 
Hence, the wholesale trade enterprises receive the largest transactional rent in agrarian business.

\begin{tabular}{|c|c|c|c|c|c|c|c|c|c|c|}
\hline \multirow{3}{*}{ № } & \multirow{3}{*}{ Type of activity } & \multirow{3}{*}{$\begin{array}{l}\text { Number } \\
\text { in a chain }\end{array}$} & \multicolumn{8}{|c|}{ Profitability of sales (\%) } \\
\hline & & & \multicolumn{4}{|c|}{ Chelyabinsk region } & \multicolumn{4}{|c|}{ Kurgan region } \\
\hline & & & 2013 & 2014 & 2015 & 2016 & 2013 & 2014 & 2015 & 2016 \\
\hline 1 & Cultivation of cattle & 1 & 1.5 & 7 & 8.3 & 4.2 & 1.3 & 3.3 & 4.2 & 6 \\
\hline 2 & Vegetable growing & 1 & 8 & 15.6 & 12.3 & -5.5 & 16.4 & 30,4 & 26.4 & 4.4 \\
\hline 3 & $\begin{array}{l}\text { Cultivation of grain } \\
\text { and leguminous } \\
\text { crops }\end{array}$ & 1 & 7.5 & 2.8 & 20.1 & 4.0 & 9.5 & 4.3 & 18.7 & 10.6 \\
\hline 4 & $\begin{array}{l}\text { Production of bread } \\
\text { and flour } \\
\text { confectionery, cakes } \\
\text { and pastries for a } \\
\text { short time to store }\end{array}$ & 2 & 18.9 & 15.0 & 11.1 & 14.7 & 16.6 & 14.8 & 13.2 & 15.2 \\
\hline 5 & $\begin{array}{l}\text { Production of flour } \\
\text { from grain, } \\
\text { production and } \\
\text { preparation of flour } \\
\text { mixes }\end{array}$ & 2 & 10.6 & 9.1 & 10.1 & 12.5 & 6.3 & 8.1 & 15.4 & 6.3 \\
\hline 6 & $\begin{array}{l}\text { Production of cocoa, } \\
\text { chocolate and sugary } \\
\text { confectionery }\end{array}$ & 2 & 13.0 & 16.7 & 15.1 & 13.0 & & & & \\
\hline 7 & $\begin{array}{l}\text { Wholesale trade of } \\
\text { sugar, chocolate and } \\
\text { sugary confectionery }\end{array}$ & 3 & 7.0 & 10.1 & 8.8 & 8.4 & 11.5 & 27.6 & 33.5 & 14.5 \\
\hline 8 & $\begin{array}{l}\text { Trade wholesale of } \\
\text { other foodstuff }\end{array}$ & 3 & 17.9 & 14.9 & 14.2 & 12.8 & 21.2 & 21.3 & 21.2 & 16.6 \\
\hline 9 & $\begin{array}{l}\text { Unspecialized } \\
\text { wholesale trade of } \\
\text { foodstuff, drinks } \\
\end{array}$ & 3 & 25.3 & 22.1 & 19.4 & 13.9 & 14.6 & 19.3 & 12.3 & 11.1 \\
\hline 10 & $\begin{array}{l}\text { Retail of meat and } \\
\text { fowl, products from } \\
\text { meat and fowl }\end{array}$ & 4 & 5.8 & 5.4 & 11.2 & 10.4 & 12.3 & 13.7 & 18.0 & 20.0 \\
\hline 11 & Retail of foodstuff & 4 & 15.5 & 13.2 & 13.2 & 11.3 & 17.0 & 13.7 & 11.2 & 14.2 \\
\hline
\end{tabular}

\section{Conclusion}

Thus, in this article the nature of a transactional rent in agrarian business is analyzed. Approaches of various theoretical schools to a rent research problem are investigated. It is revealed that rent can have two form: natural and not natural. Three features of a transactional rent are established. First, it arises in the sphere of exchange (the contractual relations). Secondly, its source is the monopolization effects in the market. Thirdly, the transactional rent has a negative effect on the level of the market imperfection. For the analysis of the transactional rent's level in agrarian business, the authors use a technique with such indicators as effectiveness ratio of the contractual relations and coefficient of opportunism. It is established that the greatest transactional rent is formed at the third element of an agrarian contract chain (wholesale trade) in the conducted statistical research.

\section{References}

Aleksandrova, N.A. (2011). Statusnaya renta v novoj politicheskoj ehkonomii (Status rent in the new political economy). Vestnik KSU of Nekrasov. №34. PP.15-20.

Andersen, J. (1777). An Inquiry into the Nature of the Corn Laws, with a view to the new Corn Bill proposed for Scotland. Edinburgh.

Bents D., Silova E. (2016). Contradiction between the subjects of the contractual relations in the regional Agrarian Sector. 18th International Scientific Conference on Economic and Social Development - "Building Resilient Society". Book of Proceedings, 2016, pp.28-38, http://www.esd-conference.com/index.php?page=past-conferences

Coase, R. The Nature of the Firm (1937). Economica, Vol. 4, No. 16, November 1937 pp. 386-405

Kovtun, O.I., Tushkova K.O. (2017). Evolyutsiya predstavlenij o zemel'noj rente soglasno vozzreniyam predstavitelej klassicheskoj shkoly (Evolution of ideas of a land rent according to views of representatives of classical school). Paperworks of XIII International sientific-practical competition: 2 parts. Penza. PP. 70-73. 
Marx, K. (1894). Capital, Volume III, subtitled The Process of Capitalist Production as a Whole. M., 1989. Part 2. 568 p.

Mesherov, A.V. (2012). Renta: retrospektivnyj analiz i sovremennost' (The rent: retrospective analysis and present). Vestnik of Samarian financial-economic Institute. 32 (14) PP. 4-10

Petty, W. (1662). A Treatise of Taxes and Contributions. Retrieved from

https://en.wikisource.org/wiki/Treatise_of_Taxes_and_Contributions_(1899)/I. 15.02.2018.

Ricardo, D. (1817). Principles of Political Economy and Taxation. Retrieved from http://ek-lit.narod.ru/ricsod.htm 11.02.2018.

Smith, A. (1776). An Inquiry into the Nature and Causes of the Wealth of Nations. M.: Eksmo, 2007. 960 p.

Sirotkin, V.B. (2014). Generatsiya renty vysshej shkoloj Generation of rent by higher school. Actual questions of economy and management. 4. PP.90-95.

Tomilov, V.A. (2010). Renta sposobnostej kak sotsial'nyj fenomen (A rent of abilities as a sochial phenomen). Vestnik VESU. №4(48) PP. 55-60. 